\title{
Corporate Social Responsibility Reporting in Banking Industry: An Analysis of Disclosure Levels in Botswana
}

\author{
Ishmael Botshabelo ${ }^{1}$, Christian J. Mbekomize ${ }^{2}$ \& Percy M. D. Phatshwane ${ }^{2}$ \\ ${ }^{1}$ Internal Audit Department, Bank of Botswana, Botswana \\ ${ }^{2}$ Senior Lecturer, Department of Accounting and Finance, University of Botswana, Botswana \\ Correspondence: Percy M. D. Phatshwane, University of Botswana, Faculty of Business, Department of \\ Accounting and Finance. P/ Bag UB 00701, Gaborone, Botswana. E-mail: phatshwane@mopipi.ub.bw
}

Received: September 22, 2017

Accepted: October 28, 2017

Online Published: November 20, 2017

doi:10.5539/ijbm.v12n12p224

URL: https://doi.org/10.5539/ijbm.v12n12p224

\begin{abstract}
This study intended to determine the disclosure levels of the CSR activities by banks in Botswana, to identify the types of information disclosed, and to determine the factors that influence the level of disclosure. The study used secondary data from the annual reports of the surveyed banks. The content analysis technique was employed and sentences that carried information relating to CSR were counted to arrive at the total of CSR reporting. Four themes of CSR, namely human resources, community involvement, environmental and ethical matters formed the bases for measuring level of CSR disclosure. The study found that a significant number of banks in Botswana are involved in CSR activities and report such engagements in annual reports. The findings of the study also suggest that the majority of banks engage extensively in and report their participation in community involvement and human resources activities. The results revealed that about two-thirds of variations in the CSR reporting levels could be explained by the combination of size, age and listing status. However, only size was found to have a positive significant relationship with CSR reporting levels. The implications of the study are that policy framework that addresses all CSR activities should be developed, and at micro level banks should come up with strategies for sustainable engagement in CSR and its disclosure.
\end{abstract}

Keywords: Corporate Social Responsibility reporting, Botswana banks, listing status, total assets, years in operation

\section{Introduction}

\subsection{Nature and importance of Corporate Social Responsibility Reporting}

It is commonly accepted that through their operations business organizations influence and are in turn influenced by the society and environment in which they operate (Shukla, 2013; Mathews, 1997). Kim (2011) submits that social problems that companies create, such as pollution, resource depletion, violations of workers' rights and excessive power of large corporations negatively affect the society in a significant way. Kim further notes that the growing attention and concerns related to those problems have moved into the public sphere. Due to this societal realization business entities are expected to disclose more information about both the activities they engage in and the effects of these activities on the environment, consumers, employees, and other public stakeholders. Hooghiemstra (2000), and Beelitz and Merkl-Davies (2012) point out that as the economy becomes more integrated, firms face increasing pressure to report and disclose their corporate social responsibility activities. A sense of social responsibility has compelled business organizations to not only be accountable for their actions, but to also report actions that affect their employees, communities, and the environment (Lawrence, Weber \& Post, 2008). It is therefore fitting that since the 1960s businesses have responded to stakeholders' expectations by engaging in what is commonly known by various designations including Social Accounting (SA), Corporate Social Responsibility Reporting (CSRR) and Corporate Social and Environmental Reporting (CSER), to mention but a few (see for example; Adams, 2008; Baker, Cohanier \& Pederzoli, 2012).

In recent decades, an increasing number of companies across the globe voluntarily issue their corporate social responsibility (CSR) reports through various media platforms including annual reports, standalone reports and company website to demonstrate their commitment to social and environmental activities (KPMG, 2005). As 
CSR endured and continued to grow in importance and impact, CSR reporting had a corresponding increase. Gray, Owen and Adams (1996) describe CSR reporting as the process of communicating the social and environmental effects of organizations' economic activities on particular interested groups within society. The authors explicate that CSR reporting involves extending the accountability of the companies beyond the traditional role of providing a financial account to the proprietors of capital. Mathews and Perera (1996) view CSR reporting as the corporate disclosure of non-financial information in addition to traditional accounting information.

Extant theoretical and empirical studies have reported that there are potential benefits associated with the reporting of CSR activities by companies. Woodward, Edwards and Birkin (1996) suggest that CSR disclosure can enhance corporate reputation by gaining the trust and support of its various stakeholders. Hosmer (1994) agrees, adding that a clear statement of a company's social responsibility stance can elicit trust and commitment between shareholders and management, thus reducing opportunistic behaviors and transactional costs. There appears to be a growing recognition of the importance stakeholders attach to social, environmental and ethical responsibilities displayed by corporations (Zadek, Raynard, Forstater \& Oelschlaegel, 1997). According to Morsing and Schultz (2006) communication relating to corporate ethics and social initiatives has the ability to evoke strong positive reactions among stakeholders regarding the virtues and intentions of the corporation. Harikkala (2010) concurs, adding that CSR reports benefit the company by offering valuable information for internal decision-making, subsequently becoming an important tool in establishing robust stakeholder relationships.

As Kolk (2004) asserts, societal value-systems that embrace firm credibility and reputation are important motivations for CSR reporting. Idowu and Papasolomou (2007) established that contemporary firms tend to report their CSR practices because it is congruent with stakeholders' expectations. Kim (2011) narrows the motivating factors of corporate reporting into two perspectives: economic and ethical motives. Economic motives refer to reputation and brand management; increased access to capital and shareholder value; risk management and improved governmental or regulatory relationship. In contrast ethical motives refer to issues pertaining to continuous and transparency in communication. These categories of motivating factors for engagement in CSR reporting are critical since the latter has the potential to magnify and bring to the fore the economic motives espoused by an enterprise.

Adams (2002) submits that beyond the reported social and business benefits, disclosing information on social and environmental issues could minimize the risks of powerful consumer boycotts. Margolis and Walsh (2003) suggest that CSR reporting often creates a real or perceived power-shift in favor of consumer groups who view such reporting as reinforcing companies' abilities to influence core businesses, thus creating a pay-off for firms that engage in CSR reporting. Adams (2002) concurs, adding that companies that produce social and environmental reports develop better internal control systems, better decision making process, and achieving some level of cost savings. This is supported by the work of Simms (2002) who associates CSR with attraction and retention of employees. A study conducted by PriceWaterhouse Coopers (2008) reported that not only were British millennial attracted to employer-brands that they admire as consumers, but that $88 \%$ of this cohort were looking for employers with CSR values that espoused their own.

CSR reporting is however fraught with its own challenges, the first being that of the lack of a governmental, regulatory or institutional requirements for CSR disclosure in many parts of the world. Discussions on acceptable and sustainable qualitative measures of disclosure are yet to commence (DeGeorge, 2010). Notwithstanding, it is the very nature and behavior of corporations that often prevents dialogue and the inception of such disclosure codes. As Sacconi (2004) notes, the adoption of a common regulatory framework on corporate sustainability reporting is difficult to address mainly because of the heterogeneity of corporations that exist globally. Interestingly one of the main adversaries to the establishment of a common CSR reporting framework is a key stakeholder, government. The absence of clear social and economic sanctions to regulate those trading in 'sin-trades' such as alcohol, tobacco and ammunitions often makes regulation and reporting of CSR activities therein difficult. This is particularly discerning when these firms fund a fair share of social and environmental projects, be it directly or indirectly through various levies, and often at the approval of governments (Barton \& Snider, 2012; Grougiou, Leventis, Dedoulis, \& Owusu-Ansah, 2014). Recognizing these challenges helps appreciate the embeddedness of CSR and CSR reporting in the broader socio-economic spectrum of business activities.

\subsection{Botswana Banking Sector}

Banks play an important role of financing other sectors in the economy, leading to economic development of any 
country (Dawood, 2014). Across Africa it is generally accepted that the banking sector is pivotal in the socio-economic development of economies (Andabai, 2011; Demirguc-Kunt, Klapper, Singer \& Van Oudheusden, 2015). In the case of Botswana the growth of the banking sector has been extensive with a reported $5.5 \%$ average real economic growth between the year 1995 and 2008 (Jefferis \& Tacheba, 2010). At the time of gaining independence Botswana had only two operating commercial banks in its territory, Barclays Bank and Standard Chartered Bank which started their operations in the 1950s as branches of South African banks (Jefferis \& Tacheba, 2010; Moffat, 2009). The enactment of Financial Institutions Act no. 8 of 1975 paved the way for the incorporation of commercial banks in the country. The pair was subsequently incorporated as independent entities, thus consequently coming under the purview of the Bank of Botswana which was established in 1975. By late 2014 there were eleven commercial banks and three statutory banks in operation across the country. All banks operating in Botswana are licensed by the Bank of Botswana in accordance with the provisions in the Banking Act (Cap 46:04, section 4). Currently there is no legislation that mandates banks to report on their corporate social responsibilities. Both the Banking Act and the Bank of Botswana licensing requirements do not refer to the need to report on CSR by banks. Thus participation in CSR activities by banks and the disclosure of such is entirely voluntary.

It is therefore notable that despite the latest global developments on CSR and CSR reporting, there are still problems in developing and emerging economies like Botswana regarding full adoption and significant visibility of the CSR reporting principles (Rahim, 2013; Chhabra, 2014). Similarly, the extent of CSR reporting, the motivation behind engaging or not engaging in CSR reporting and the aspects of CSR matters being reported by banks in Botswana have not been extensively researched.

The ubiquitous nature of banks' operations expands their CSR as they have the potential to directly or indirectly impact a wider portion of society and the environment. This papers attempts to analyze the nature of CSR in Botswana banks, their level of CSR reporting and what influences it. The paper contributes to the knowledge of how banks attempt to achieve corporate citizenship and adds to the CSR reporting literature in developing countries. The paper also provides recommendations on how efforts to build sustainable CSR strategies can be improved.

The rest of the paper discusses CSR and CSR reporting in banks and theories explaining the motives for voluntary CSR disclosures. The paper continues to present the hypotheses to be tested, methodology employed by the study, and results and discussions. It ends with conclusions and recommendations.

\section{Literature Review}

\subsection{Corporate Social Responsibility (CSR) in Banks}

As financial intermediaries in society banks have come to occupy a focal position in contemporary society through their active role in pricing and valuing financial assets, managing financial risks and being at core of the payment system. These functions have a huge impact on the way society functions, and extends banks' responsibilities for the state of communities they serve (Lachowicz, 2000; Greenbaum \& Thakor, 2007). Decker (2004) asserts that in commercial banking CSR falls within the realm of social issues, and that this sector has the capacity to change CSR practices across the business spectrum. Although commercial banks do not engage directly in environmentally hazardous activities as compared to resource extraction or heavy industry sectors, Thompson and Cowton (2004) note that banks can be seen as facilitators of industrial activities which are often detrimental to the environment by virtue of their intermediary financing function.

Scholtens (2006) suggests that when banks provide finance, a triad of goals related to economic, social and environmental performance should be considered; that is, the loan has to be repaid at a decent return and there must be an improvement in social and environmental performance resulting from the transactions. The consideration of these goals demonstrates the deeply entrenched CSR consciousness of commercial banks. De la Cuesta-González, Muñoz-Torres, and Fernandez-Izquierdo (2006) assert that the main social function of financial institutions includes accountability for any direct and indirect economic, social and environmental impacts. There is therefore a strong argument for social contracts between banks' core business and society. This argument is highlighted by Wagg (2010) who observes that before the financial crisis unfolded in 2007, banks could undertake some non-core projects such as microcredit, but in the post-crisis era the responsibility revolves around the core business and how banks act in their advisory capacity.

Further to this ideology, Richards, Palmer and Bogdanova (2008) provided a perspective that condemns irresponsible business practices exhibited by financial institutions through excessive or irresponsible lending. Their view is that, matching credit to its demand is sometimes justified by the financial institutions with declarations of having to meet widening social choices. This, however, can create human misery and financial 
distress when customers are unable to make the ensuing payments.

Mayo (1997) adds to this debate by noting that at the very least, banks have a broad responsibility of understanding the social impact of major actions they undertake, and to minimize the costs to society. According to Strandberg (2005) one would expect best-practice CSR financial institutions to have a key role in engaging stakeholders in their efforts to solve complex social problems, and to keep abreast of stakeholder concerns. Cowton (2002) asserts that both financial institutions and borrowers have responsibilities in a loan contract. However, other stakeholders can be affected should they fail in their responsibilities, and in this respect Cowton and Thompson (2000) provide examples of banks being called upon to recognize the indirect environmental impacts of their lending activities. Argandoña (2009) notes that after considering the number-of-borrowers who had repayment problems in the United States during the 2007 financial crisis, financial institutions seem to have failed in their corporate responsibilities by securing subprime rate to borrowers.

According to the Global Reporting Initiative (GRI, 2007), the indirect environmental impacts associated with financial products and services are an area of intense interest to many stakeholders. It argues that these impacts can be significantly greater in scale than direct impacts of financial institutions' operations, such as the amount of energy consumed or volume of waste generated. This calls for the banks to be socially responsible for their indirect environmental impacts. Bouma, Jeucken, and Klinkers (2001) state that, financial institutions are considered to be 'clean' of any adverse environmental impact but, despite this, earlier initiatives have been implemented to measure consumption of electricity, heat, paper and carbon monoxide emission. They cite the case of Triodos Bank that had adopted a renewable solar energy to support its operations, the other example being the introduction of the first biodegradable credit card to reduce its carbon pollution by the UK Co-operative Bank in 1997.

Lou and Bhattacharya (2006) investigated CSR activities of Fortune 500 companies and concluded that there is a direct link between CSR and customer satisfaction. Researchers have also found a positive relationship between CSR and "word of mouth" about firms that engage in actions that are considered socially responsible (Handelman \& Arnold, 1999; Szymanski \& Henard, 2001). Zappi (2007) notes that banks have realized that the concept of CSR impacts on their operating environment, and that it has significant consequences on their survival.

Doane (2005) argues that socially responsible banks need to address a variety of issues, including therein environmental sustainability and disassociation with socially unconscious companies and individuals. In the author's opinion, a socially responsible bank would place the needs of its customers and those of society above those of its shareholders. The researcher further reasons that in the short term, such a bank may lose the support of shareholders, but the positive publicity generated by behaving responsibly might offset some of the lost support. Abou-El-Fotouh (2011) argues that there are obvious and real gains on hand for banks which have well-designed and successful CSR strategies. Such entities can promote their profile in the community they serve, enhance local economic performance and enable community development, at the same time strengthening their profitability.

In addition to traditional charitable donations, CSR focuses on how companies and financial institutions can contribute through their core business. It is argued that financial services institutions are in a relatively powerful position to encourage CSR adoption or to discourage anti-CSR activities on the part of their clients (Thompson \& Cowton, 2004). Through their core business activities, or indirectly through the activities of their clients, financial services institutions have gained enormous economic, social and environmental influence on society (Bouma, Jeucken, \& Klinkers, 2001; Scholtens, 2006).

Abou-El-Fotouh (2011) identified five areas in which banks should link their operations with CSR. These areas include project financing, community involvement, awareness and transparency, environment and financial inclusion. In respect to project finance, banks are expected when implementing their core business of credit and investment, to consider their responsibility to prevent or limit social and environmental harm that emanating from activities of financed projects by the adoption of appropriate analysis and verification procedures. Community involvement is viewed as the basis of all accomplished CSR policy initiatives and should extend beyond standard charitable measures. This is more pertinent in developing economies where disadvantaged sectors of society demand greater support on social and environmental issue such as recycling and waste management, health support programs, and sponsorship of underprivileged sectors of these communities (Dorasamy, 2013).

\subsection{Corporate Social Responsibility Reporting (CSRR) in Banks}

Banking is a competitive industry, thus engaging in CSR activities and reporting them can lead to gaining 
competitive advantage. Hillman and Keim (2001) view CSR as a valuable tool for creating reputational capital in the form of good corporate image and enhanced reputation, in turn affording the firm desired advantage over competitors. Hamid (2004) studied CSR disclosure in annual reports by banks and finance companies in Malaysia and found that product-related disclosures appear to be more prevalent than environmental, human resources or community related disclosure. The results also revealed that size, listing status and age of business are positively associated with social responsibility disclosure, while profitability had little or no influence.

Branco and Rodrigues (2006) conducted a study to ascertain whether banks in Portugal use their websites as a medium of disclosing social responsibility information and of also identifying the type of information they disclosed. Their findings suggested that Portuguese banks appear to give greater importance to annual reports as disclosure media than websites. Their study further revealed that banks with higher visibility among consumer-groups showed greater concern to improve their image through high CSR disclosure in annual reports. A study by Nikolaou (2007) on the Greek banking sector found that CSR information is disclosed on an ad-hoc environment accounting basis with respect to environmental management, environmental accounting, as well as stakeholder engagement. In the study by Clarke and Gibson-Sweet (1999), banks and other retail outlets were found to make considerable community involvement disclosures. The argument for the relation was that companies belonging to both sectors have a name highly recognized among the public. In the same study banks were found to have lower levels of environmental disclosure than stores.

Branco and Rodrigues (2006) argue that banks can report on their activities to ensure that their lending and investment policies do not facilitate industrial activities that are detrimental to the environment. This is because they consume large amounts of resources, and generate waste, and as such their policies regarding their contribution to conservation of energy and natural resources should be important aspects of their social responsibilities, and should be reported in one form or another.

Tarna (1999) examined environmental reports by banks and insurance companies worldwide and determined that their CSR reports focused more on environmental issues rather than social matters. However the study noted that there were indications of rising trend towards the disclosure of social matters. Douglas, Doris and Johnson (2004) examined CSR disclosure in annual reports and websites of Irish banks and other financial institutions over a 5year period between 1998 and 2002. The results of their study revealed that the most reported issues in the annual reports were corporate governance and human resources whereas community involvement was least reported. The results also indicated that none of the banks made any environmental policy disclosure. Abu-Baker and Nasser (2000) found that all companies surveyed in the banking and insurance industries disclosed information on human resources and community involvement.

According to Adams, Hill and Roberts, (1998) it appears that issues like firm size, industry type, profitability and country influence the extent of corporate social reporting by entities. The work of Dineshwar (2013) in Mauritius revealed that banks with huge number of automatic teller machines (ATMs) and those listed with stock exchange tended to disclose more of their CSR information.

\subsection{Research Theories}

Given that CSR reporting is to a large extent voluntary various scholars have developed theories to explain the motives behind deliberate dissemination of information about corporate social and environmental activities and their impacts. It is outside the scope of this paper to prove any of these theories or to develop another one, but it attempts to explore what have been the underlying explanations behind the intentional disclosure of corporate social responsibilities activities. These theories include, inter alia, stakeholder theory, legitimacy theory, political economy theory, positive accounting theory, and institutional theory. This study drew on the notions of stakeholder and legitimacy theories which have been similarly adopted by other studies (see for example O’Donovan, 2002; Deegan \& Gordon, 1996; Gray et al, 1996).

\subsubsection{Stakeholder Theory}

The stakeholder theory is an organizational management and business ethics theory that postulates that stakeholders-group have influence on businesses and in turn, stakeholders are affected by the operations of the businesses (Mitroff, 1983; Price, 2004). The theory assumes that enterprises think beyond profit maximization and consider potential impacts on non-stockholding groups. Freeman (1984) developed the stakeholder theory to highlight the interplay and communication between an organization and its stakeholders. The theory was later expounded by Mitchell, Agle and Wood (1997) who focused on explaining how to identify the types of stakeholders and why managers respond to one group of stakeholders differently from another. The authors argued that stakeholders can be put in three main categories based on their power to influence the firm, their legitimate relationship with the firm and their urgency of claims from the firm. This leads to three attributes of 
stakeholders: power, legitimacy and urgency. The authors further theorized that due to the fact that managers are in contract with all other firm's stakeholders and have direct control over decision making mechanisms within the firm, they normally pay attention to the claims or relationships of a particular stakeholders-group depending on how they perceive the salience of that group. According to Bearle \& Meanse (2002) CSR places emphasis on the role of stakeholders, stressing the fact that a firm cannot function independently from its environment. Therefore there should be communication of the CSR activities by the organization to the stakeholders as a way of achieving transparency.

According to stakeholder theory, increased CSR makes business establishments more attractive to stakeholders, and as such enterprises should engage in CSR ventures (Nikolova \& Arsić, 2017). Pioneered by Falck and Heblich (2007), this thinking led to the assertion that CSR can be strategically applied in dealings with the interests of each stakeholder. CSR disclosures in the annual reports or specific report on CSR are seen as part of the dialogue between the business and its stakeholders. The theory further affirms that, the more powerful the stakeholders are, the more the company must adapt to their interests. Carroll (1991) posits that, there is a natural fit between the idea of CSR and the company's stakeholders. According to Friedman and Miles (2002) there are two branches of stakeholder theory, ethics (moral) and power (influence). From the ethics view-point, Deegan (2002) calls for all stakeholders to be treated fairly by companies and without the expectation of improved financial performance (Gray et al, 1996; Hasnas, 1998). Stakeholders' power approach suggests that disclosure of social responsibility information is used to manage company's relationship with various groups of stakeholders. The company would disclose the information depending on how it views stakeholders' power in controlling the resources needed by the company (Branco \& Rodrigues, 2006). Roberts (1992) reports a significant relationship between stakeholders' power and extent of CSR reporting.

\subsubsection{Legitimacy Theory}

CSR reporting has also been discussed within the theoretical framework of legitimacy theory. Dowling and Pfeffer (1975) suggest that legitimacy theory is useful in analyzing corporate behavior. Their explanation for the activities organizations engage in is that organizations seek to establish congruence between the social values associated with their activities and the norms of acceptable behavior in the larger social system in which they operate. In support of legitimacy theory Deegan (2002) suggests that organizations need to take community expectations into consideration if their desire is to be successful as they will be punished for not participating in a manner consistent with community expectations. According to Branco and Rodrigues (2006) when society's expectations are not fulfilled, that is, a company's actual or perceived behavior is not in accordance with social values and norms, a legitimacy gap may develop. Legitimacy gap arise when there is no congruence between society's expectation and perception of a company's activities and actions (Tilling, 2004). Some suggested that causes of legitimacy gaps include company performance changes while societal expectations of company performance remain the same (Wartick \& Mahon, 1994); or societal expectations of company performance change while corporate performance remain the same.

According to Brown and Deegan (1998), legitimacy theory conjectures that companies ensure that they execute their activities within the framework (norms and bounds) of the society within which they operate. Shocker and Sethi (1974) note that any social institution and business in no exception operates in a society via a social contract, expressed or implied, on which its growth and survival are based. The societal bounds and norms change over time, requiring businesses to demonstrate that their actions are legitimate. Engagement in CSR activities can be seen as an effective demonstration of legitimacy. Studies by Patten (1991 and 1992) demonstrate that the volume of CSR disclosures are particularly high when a company or the industry in which it operates is challenged by adverse business conditions, such as litigation, environmental pollution and human rights violation. Patten (1992) suggests that the firm's response to negative occurrences in the media or elsewhere is by mitigation through social information in annual reports. Patten (1991) and Branco and Rodrigues (2006) use legitimacy as a framework to investigate social disclosure practices in Portuguese and Alaskan banks. Branco and Rodrigues (2006) found that Portuguese banks engage in selective disclosure of CSR activities in certain media outlets depending on the user of the media outlet. As such, environmental and human resources reports will be disclosed through the internet, whereas customer-related CSR activities are primarily found in annual reports.

\section{Hypotheses}

\subsection{Entity Size and CSR Reporting}

Entity size can be measured using different variables such as number of the employees, turnover, total assets and market share. In the banking industry other factors such as the number of branches and number of ATMs can also 
be used to measure the size of the banks (Dineshwar, 2013). The current study uses total assets of the bank to represent size of the enterprise. Damak-Ayadi (2010) suggests that corporate size has an impact on the level of social responsibility activities and their disclosure, the reason being that larger companies are more likely to be scrutinized by the general public. Brammer and Pavelin (2008) observe that larger firms receive more attention from the public as these firms are more likely to be diversified across geographical and product market, thereby amassing a larger and more diverse stakeholder groups. Larger companies undertake more activities, make a greater impact on society, and have grander shareholder-base which is to be more concerned with social programmes undertaken by the company (Hackston \& Milne, 1996). Alsaeed (2006) found that firm size was significantly positively associated with the level of disclosure, however, debt, ownership dispersion, age, profit margin, industry were found to be insignificant in explaining the variation of voluntary disclosure. However, a study conducted in Botswana by Mbekomize and Dima (2013) on environmental disclosure by parastatals and companies listed on the Botswana Stock Exchange found that company size is not a good predictor of the level of social and environmental disclosure. It is therefore hypothesized that:

$\mathrm{H}_{0} 1$ : There is no significant positive relationship between the size of the bank and extent of CSR reporting.

\subsection{Stock Exchange Listing Status}

In the context of Botswana, the Botswana Stock Exchange is mandated to operate and regulate the equities and fixed interest securities market. It was established in 1989 and it currently hosts companies from varieties of industries including therein banking and financial services, wholesaling and retailing, tourism and information and technology. The current study covered both BSE listed and unlisted banks.

The current requirements for listing on the exchange do not compel companies to be engaged in CSR reporting. In Botswana, the results of Mbekomize and Dima (2013) showed that listed companies tend to disclose their social and environmental information more than parastatals. A study by Mishra and Suar (2010) investigated whether CSR influence the financial and non-financial performance in Indian firms. Their findings suggested that listed firms show responsible business practices and better financial performance than the non-listed firms. It is therefore hypothesized that:

$\mathrm{H}_{0}$ 2: There is no significant positive relationship between listing with stock exchange and extent of CSR reporting.

\subsection{Entity Age}

The age of commercial banking business can be best determined by looking at two factors, particularly in the case of Botswana. These are the date of granting the license by the bank of Botswana as the regulatory authority responsible for issuing banking licenses and the date when the licensed business commenced banking operations in Botswana. This study focuses on the latter. Roberts (1992) suggests that firm age is significantly related to CSR and environmental disclosures and finds a positive relationship between the two. There are arguments that explain why younger firms are less likely to report social responsibility information than older ones. For instance, younger firms are smaller and have fewer issues to report than older ones. Parsa and Kouhy (2008) argue that, younger firms may be more reluctant to disclose information as they may be price-sensitive, not least because of the competition they encounter. According to Firth (1979) firms that have been in establishment over a longer period tend to disclose more information than newly-established firms. It is therefore hypothesized that:

$\mathrm{H}_{0} 3$ : There is no significant positive relationship between age of operations of the bank and extent of CSR reporting.

\section{Methodology}

\subsection{Study Population}

With the exception of three banks, all commercial and statutory banks operating in Botswana as at December 2014 were selected for analysis by the current study. Bank of India (Botswana) Limited, State Bank of India (Botswana) Limited and Kingdom Bank Africa Limited were excluded from the study because they began their operations after 2012, the first year of our observation. The population includes all banking institutions that are regulated by Bank of Botswana, and as such required to submit annual returns to the Central Bank. The list of the banking institutions surveyed is provided in Table 1 . 
Table 1. Banks covered by the study

\begin{tabular}{|c|c|c|c|c|c|}
\hline Institution & $\begin{array}{l}\text { Operating } \\
\text { since }\end{array}$ & Bank Type & $\begin{array}{l}\text { Business } \\
\text { Locations } \\
(2014)\end{array}$ & $\begin{array}{l}\text { Listing } \\
\text { Status }\end{array}$ & $\begin{array}{l}\text { ATMs } \\
(2014)\end{array}$ \\
\hline Barclays Bank of Botswana Limited & 1975 & Commercial & 41 & Listed & 116 \\
\hline Standard Chartered Bank Botswana Limited & 1975 & Commercial & 15 & Listed & 68 \\
\hline First National Bank of Botswana Limited & 1990 & Commercial & 22 & Listed & 172 \\
\hline Stanbic Bank Botswana Limited & 1992 & Commercial & 11 & Unlisted & 26 \\
\hline Bank of Baroda ( Botswana) Limited & 2000 & Commercial & 3 & Unlisted & 6 \\
\hline Bank of Gaborone Limited & 2006 & Commercial & 7 & Unlisted & 18 \\
\hline Capital Bank Limited & 2008 & Commercial & 4 & Unlisted & 4 \\
\hline $\begin{array}{l}\text { African Banking Corporation of Botswana Limited } \\
\text { (BancABC) }\end{array}$ & 2008 & Commercial & 8 & Listed & 10 \\
\hline Botswana Savings Bank & 1992 & Statutory & 2 & Statutory & 0 \\
\hline National Development Bank & 1963 & Statutory & 4 & Statutory & 0 \\
\hline Botswana Building Society & 1976 & $\begin{array}{l}\text { Building } \\
\text { society }\end{array}$ & 10 & Statutory & 12 \\
\hline
\end{tabular}

*Sources: Bank of Botswana Banking Supervision Annual Reports (2014, pp.4 \&45).

\subsection{Data Collection Procedures}

The analysis of CSR reporting in this study was conducted by reviewing the annual reports of 8 commercial banks, 2 statutory banks and 1 building society over a three-year period from 2012 to 2014 . The appearance is that a majority of studies into CSR globally have used corporate annual reports as the exclusive sampling unit (Campbell, 2004), with a number of reasons being advanced for their use. Not only are annual reports easily accessible to researchers, they are often accepted as an appropriate source for revealing company's attitudes towards social reporting (Campbell, 2000). It has also been argued that annual reports are the single most important source of information on corporate activities (Adams et al., 1998). Furthermore, from an accounting perspective, explanations are most frequently being sought for voluntary disclosure from annual reports, be it on audit activities, taxation, risk or governance structure (Hawashe \& Ruddock, 2014; Savage, Cataldo \& Rowlands, 2000). Despite these assertions, Zeghal and Ahmed (1990) argue that the reliance on annual reports may present an incomplete picture of CSR activities since these are often not the only medium through which companies report their socially responsible behavior; a view supported by Unerman (2000), as well as by Milne and Adler (1999).

This study uses content analysis as a method of gathering data from annual reports. Guthrie and Abeysekera (2006) reported that content analysis has been heavily used in evaluating the extent of CSR disclosures appearing in annual reports. Consistent with prior studies on CSR reporting, this study selected four testable dimensions of environment, community involvement, human resources and ethical and other disclosures (Tsang, 1998; Guthrie \& Parker, 1989; Ismail \& Ibrahim, 2008). These major dimensions were sub-divided into 22 sub-themes which guided the sentence counting (See Table 3).

The unit of analysis for this study was number of sentences as opposed to number of words, number of pages or paragraphs. According to Guthrie and Abeysekera (2006) number of sentences is the mostly used unit of analysis in CSR studies. The frequent use of sentences to measure the extent of CSR reporting in annual reports is supported by the argument that sentences do not require a lot of judgment when counting and fewer errors are expected (Ismail \& Ibrahim, 2008). In instances where sentences were repeated in different sections of the annual report, for example, Chairman's report, Managing Director's report and Sustainability report, they were counted more than once to capture the frequency of reporting which was the aim of the study.

\subsection{Model Specification}

The study employed ordinary least square (OLS) technique of the regression model to test the formulated hypotheses. The regression model was formulated as follows: 


$$
C S R \text { reporting }=\alpha+\beta 1 S I Z E+\beta 2 \text { LISTED }+\beta 3 A G E+\varepsilon
$$

Where:

CSR reporting $=$ the extent of CSR reporting by number of sentences

$\mathrm{a}=\mathrm{a}$ constant term representing number of sentences disclosed regardless of size, listing status and or age.

SIZE $=$ size of the bank measured by total assets value

LISTED = " 1 " if the bank is listed with BSE, and " 0 " if it is not listed.

$\mathrm{AGE}=$ the number of years the Bank has been operating in Botswana.

$\varepsilon \quad=$ error term

\section{Results and Discussion}

\subsection{Descriptive Statistics}

Descriptive statistics of the data analyzed by this study is reflected on Table 2. According to Table 2 the Botswana banking industry is made up of some banks which have been in operation for almost half a century and others which have been in operation for only 4 years. This implies that the industry is still growing as new entrants are still joining the sector. In addition, the industry comprises of small banks with total assets value of just above one million Pula (Note 1) and large banks with asset values amounting to around 17.6 million Pula.

Table 2. Descriptive statistics

\begin{tabular}{llllll}
\hline & $\mathrm{N}$ & Minimum & Maximum & Mean & Std. Deviation \\
\hline Years in Operation & 33 & 4 & 51 & 23.45 & 14.975 \\
BSE Listing & 33 & 0 & 1 & 0.36 & 0.489 \\
Total assets in BWP & 33 & 1068172 & 17639406 & 6991897.94 & 5916481.68 \\
CSR Reporting (No. of sentences) & 33 & 0 & 150 & 32.03 & 39.298 \\
\hline
\end{tabular}

\subsection{CSR Sentences Reported}

Most of the banks examined are yet to embrace the idea of raising their capital through equity market. Only three out of eleven banks (27\%) were listed with the Botswana Stock Exchange. It interesting to note that over the three-year period of the study three banks did not engage in any reportable CSR activity at one time or another. Coincidentally, the maximum number of sentences disclosed and the maximum total assets observed in Table 2 relate to a single company over one-year period.

The analysis of annual reports of 11 banks operating in Botswana for period 2012 to 2014 provided the source of primary data analyzed by this study and generated 33 observations for correlations and regression analysis.

Table 3. CSR Sentences Reported by Banks

\begin{tabular}{|c|c|c|c|c|c|c|c|c|}
\hline & 2012 & & 2013 & & 2014 & & & \\
\hline & $\begin{array}{l}\text { No. Banks } \\
\text { Disclosing }\end{array}$ & $\begin{array}{l}\text { Sentences } \\
\text { Disclosed }\end{array}$ & $\begin{array}{l}\text { No. Banks } \\
\text { Disclosing }\end{array}$ & $\begin{array}{l}\text { Sentences } \\
\text { Disclosed }\end{array}$ & $\begin{array}{l}\text { No. Banks } \\
\text { Disclosing }\end{array}$ & $\begin{array}{l}\text { Sentences } \\
\text { Disclosed }\end{array}$ & $\begin{array}{l}\text { Total } \\
\text { Sentences }\end{array}$ & Percentages \\
\hline \multicolumn{9}{|l|}{$\begin{array}{l}\text { Human Resources } \\
\text { Disclosures }\end{array}$} \\
\hline $\begin{array}{l}\text { Staff welfare and } \\
\text { safety }\end{array}$ & 3 & 8 & 3 & 12 & 3 & 15 & 35 & 3.31 \\
\hline $\begin{array}{l}\text { Staff training and } \\
\text { development }\end{array}$ & 6 & 31 & 4 & 31 & 5 & 24 & 86 & 8.14 \\
\hline $\begin{array}{l}\text { Staff remuneration } \\
\text { policy }\end{array}$ & 1 & 6 & 3 & 12 & 4 & 14 & 32 & 3.03 \\
\hline $\begin{array}{l}\text { Union Management } \\
\text { Relations }\end{array}$ & 2 & 18 & 2 & 11 & 4 & 20 & 49 & 4.64 \\
\hline Employee & & & & & & & & \\
\hline $\begin{array}{l}\text { Motivations \& Job } \\
\text { Satisfaction }\end{array}$ & 1 & 2 & 1 & 2 & 4 & 14 & 18 & 1.7 \\
\hline
\end{tabular}




\begin{tabular}{|c|c|c|c|c|c|c|c|c|}
\hline Sub-total & & 65 & & 68 & & 87 & 220 & 20.81 \\
\hline \\
\hline \multicolumn{9}{|l|}{ Involvement } \\
\hline \multicolumn{9}{|l|}{ Disclosures } \\
\hline $\begin{array}{l}\text { Community Social } \\
\text { investment }\end{array}$ & 2 & 14 & 6 & 93 & 2 & 9 & 116 & 10.97 \\
\hline $\begin{array}{l}\text { Financial literacy \& } \\
\text { inclusion }\end{array}$ & 1 & 9 & 0 & 0 & 2 & 5 & 14 & 1.32 \\
\hline $\begin{array}{l}\text { Employee } \\
\text { volunteering }\end{array}$ & 3 & 20 & 4 & 30 & 2 & 19 & 69 & 6.53 \\
\hline $\begin{array}{l}\text { Reaching to unbanked } \\
\text { funds }\end{array}$ & 0 & 0 & 0 & 0 & 0 & 0 & 0 & 0 \\
\hline $\begin{array}{ll}\text { Sponsorship } & \text { of } \\
\text { sporting activities } & \end{array}$ & 1 & 1 & 3 & 15 & 5 & 18 & 34 & 3.22 \\
\hline $\begin{array}{l}\text { Public welfare and } \\
\text { health }\end{array}$ & 1 & 3 & 4 & 31 & 4 & 21 & 55 & 5.2 \\
\hline Arts and culture & 3 & 5 & 1 & 6 & 2 & 8 & 19 & 1.8 \\
\hline Education aid scheme & 1 & 9 & 1 & 6 & 5 & 31 & 46 & 4.35 \\
\hline $\begin{array}{ll}\text { Support } & \text { socially } \\
\text { disadvantaged groups }\end{array}$ & 3 & 6 & 3 & 35 & 3 & 23 & 64 & 6.05 \\
\hline $\begin{array}{l}\text { Economic } \\
\text { empowerment }\end{array}$ & 1 & 3 & 1 & 1 & 3 & 8 & 12 & 1.14 \\
\hline Financial inclusion & 1 & 7 & 0 & 0 & 2 & 8 & 15 & 1.42 \\
\hline $\begin{array}{l}\text { Community support } \\
\text { programmes }\end{array}$ & 8 & 88 & 2 & 12 & 7 & 84 & 184 & 17.42 \\
\hline Sub-total & & 165 & & 229 & & 234 & 628 & 59.42 \\
\hline Environmental & & & & & & & & \\
\hline Disclosures & & & & & & & & \\
\hline $\begin{array}{l}\text { Environment } \\
\text { protection }\end{array}$ & 2 & 12 & 1 & 6 & 3 & 12 & 30 & 2.84 \\
\hline $\begin{array}{l}\text { Ecological supply } \\
\text { chain }\end{array}$ & 1 & 10 & 0 & 0 & 2 & 7 & 17 & 1.61 \\
\hline $\begin{array}{l}\text { Institution concern for } \\
\text { environment }\end{array}$ & 4 & 21 & 1 & 12 & 2 & 3 & 36 & 3.41 \\
\hline Sub-total & & 43 & & 18 & & 22 & 83 & 7.85 \\
\hline $\begin{array}{l}\text { Ethical and other } \\
\text { CSR disclosures }\end{array}$ & & & & & & & & \\
\hline $\begin{array}{l}\text { Integrity-being a } \\
\text { responsible company }\end{array}$ & 2 & 10 & 0 & 0 & 1 & 3 & 13 & 1.23 \\
\hline $\begin{array}{l}\text { Ethical/professional } \\
\text { conduct }\end{array}$ & 1 & 1 & 0 & 0 & 1 & 1 & 2 & 0.19 \\
\hline $\begin{array}{l}\text { Financial crime } \\
\text { combating }\end{array}$ & 1 & 3 & 2 & 7 & 2 & 3 & 13 & 1.23 \\
\hline $\begin{array}{l}\text { Responsible selling } \\
\text { and marketing }\end{array}$ & 1 & 3 & 0 & 0 & 1 & 1 & 4 & 0.38 \\
\hline Consumer complaints & & & & & & & & \\
\hline $\begin{array}{l}\text { \&customer } \\
\text { satisfaction }\end{array}$ & 3 & 20 & 2 & 17 & 5 & 29 & 66 & 3.24 \\
\hline Other & 0 & 0 & 2 & 28 & 0 & 0 & 28 & 2.65 \\
\hline Sub-total & & 37 & & 52 & & 37 & 126 & 11.92 \\
\hline Grand Total & & 310 & & 367 & & 380 & 1057 & 100 \\
\hline
\end{tabular}

Table 3 indicates the number of sentences disclosed by commercial banks under each category over the 3 year period from 2012 to 2014 . The table also reflects the number of banks that disclosed particular information. The data shows that the mostly disclosed category of corporate responsibility activities is community involvement which accounts for $59 \%$ of the total disclosures, followed by human resources category at $21 \%$. According to 
Table 3 the least disclosed group of activities are environmental issues reflecting only $8 \%$ level of disclosure implying that banks do not typically concern themselves with environmental issues. This finding is consistent with the findings of Douglas et al. (2004) who report that Irish banks did not report extensively on environmental engagement.

Under community involvement four subthemes, namely community support programmes, community social investment, employees volunteering and support of socially disadvantaged groups in that order of preeminence of disclosure were the most extensively reported activities. Staff development and union management relations were the top two disclosed activities under human resource category. Customer satisfaction and fighting financial crime reflected relatively high number of sentences under ethical and other issues category. These findings are consistent with findings of Abu-Baker and Nasser (2000) who reported that companies in banking and insurance industries had a tendency of heavily disclosing their human resources and community involvement activities. These results also support the findings of Douglas et al, (2004) who found that human resources matters were vastly reported in Irish banks. However, contrary to the results of this study Douglas et al, (2004) noted that community involvement was least reported. This could be reflective of the apparent contrast between the developed world and developing countries' governments in provision of social welfare support to the public. In the former countries governments are immensely involved in community support through welfare expenditures and therefore there is no urgent need for the corporate world to be similarly engaged. However, in developing countries where government involvement in community support is restricted due to number of factors including lack of resources, the corporate world ceases the opportunity to become corporate citizens by heavily engaging in community support activities (Sedler, 1967; Gough, 2008).

An increasing trend of disclosure over the three year period was reflected in both human resources and community involvement activities. Environmental and ethical disclosures did not reflect any discernible trend. While the number of sentences disclosed under environmental category in 2013 dropped significantly by $58 \%$ as compared to 2012 it increased by $22 \%$ in 2014 . Under ethical issues category the number of sentences disclosed rose by about $41 \%$ in 2013 as compared to 2012 and dropped to 2012 levels in 2014 . However, the general picture depicted by the findings of this study is that the volume of CSR disclosure was on the rising trajectory over the three year period.

\subsection{Correlations}

Table 4 displays the correlation between each of the independent variables and dependent variable and the association within the independent variables. A very weak positive and insignificant correlation was revealed between the number of years a bank has been in operation and its listing status $(\mathrm{r}=0.103, p=0.569)$. In addition, a very weak negative and insignificant relationship existed between years in operation and total assets $(r=-.004$, $p=0.980$ ). A significant moderate positive relationship was reflected between total assets and listing with the Botswana Stock exchange $(\mathrm{r}=0.635, p=0.000)$. This implies that banks with substantial total assets are more likely to seek listing with the stock exchange.

Tables 4. Correlation among variables

\begin{tabular}{llll}
\hline & & Years in operation & BSE listing \\
\hline Years in operation & Pearson Correlation & & \\
& Sig. (2-tailed) & & \\
BSE listing & Pearson Correlation & .103 & \\
& Sig. (2-tailed) & .569 & $.635^{* *}$ \\
Total assets & Pearson Correlation & -.004 & .000 \\
& Sig. (2-tailed) & .980 & $.576^{* *}$ \\
CSR Reporting & & .229 & .001 \\
\hline
\end{tabular}

**. Correlation is significant at the 0.01 level (2-tailed).

The results also reflected a significant high positive $(\mathrm{r}=0.770, p=0.000)$ and significant moderate positive $(\mathrm{r}=$ $0.576, p=0.001$ ) association between level of disclosure and total assets and listing status respectively. A weak positive relationship $(\mathrm{r}=0.229, p=0.241)$ between years of operation and disclosure level was revealed by the study. 


\subsection{Regression Analysis}

Table 5 presents the results of the multiple regression analysis model used to find the predictive power of bank size, period of operations and stock exchange listing status over the level of CSR reporting.

Table 5. Regression coefficients for independent variables

\begin{tabular}{|c|c|c|c|c|c|c|c|c|c|}
\hline \multirow[b]{2}{*}{ Variables } & \multirow[b]{2}{*}{ Coefficient } & \multirow[b]{2}{*}{$\mathrm{t}$-value } & \multirow[b]{2}{*}{ Sig } & \multicolumn{2}{|c|}{ Collinearity Statistics } & \multicolumn{2}{|c|}{ Model Summary } & \multicolumn{2}{|c|}{ ANOVA } \\
\hline & & & & Tolerance & VIF & R-Square & $\begin{array}{l}\text { Adjusted } \\
\text { R-Square }\end{array}$ & $\mathrm{F}$ & Sig \\
\hline CSR reporting & & & & & & 0.659 & 0.616 & 15.466 & 0.000 \\
\hline Years in operation & 0.232 & 1.932 & 0.065 & 0.986 & 1.014 & & & & \\
\hline BSE Listing & 0.117 & 0.759 & 0.455 & 0.595 & 1.680 & & & & \\
\hline Total Assets & 0.700 & 4.543 & 0.000 & 0.599 & 1.670 & & & & \\
\hline
\end{tabular}

In its entirety, the model reflected a statistically significant relationship between level of disclosure of corporate responsibility information and three independent variables of total assets, years of operations and listing status. The model presented the adjusted R-square of 0.616 which means that about $62 \%$ of variations in the disclosure level can be attributed to three independent variables. The model also yielded a statistically significant F-ratio suggesting that the combination of bank size, period of operation and listing with a stock exchange form a force capable of influencing the bank's extent of reporting corporate responsibility matters.

However, when considered individually, not all independent variables in the model appeared to have a significant influence on the disclosure level. Only bank size as represented by total assets apparently had a moderate positive and statistically significant explanatory power to reporting levels. The regression results revealed that $70 \%$ of variations in reporting levels could be explained by total assets and the likelihood that these results could have been by chance is zero $(\beta=0.700, p=0.000)$. Therefore the hypothesis that proposed that there is no significant positive relationship between the size of the bank and extent of CSR reporting is rejected. These findings concur with prior studies which reported that company size influences CSR activities information dissemination (see for example, Ismael \& Ibrahim, 2008; Dhar \& Mitra, 2010). Public pressure and adequacy of resources have been mentioned as key reasons for large entities having the tendency to disclose significant amount of information about their CSR activities. The regression model further showed that only $23 \%$ of fluctuations in the level of CSR reporting could be associated with the years the bank has been operating in the country. However, this association was not statistically significant $(\beta=0.232, p=0.065)$. Therefore the hypothesis which assumed that there is no significant positive relationship between period of operation of the bank and extent of CSR reporting is accepted. Among the three independent variables, listing status emerged as the weakest explanatory factor of CSR reporting levels. The model revealed that only $11 \%$ of changes in the disclosure levels could be associated with the fact that the bank was listed with the Botswana Stock Exchange $(\beta=0.117, p=0.455)$. Therefore the hypothesis that predicted that there is no significant positive relationship between bank listing and extent of CSR reporting was confirmed.

\section{Conclusion and Recommendations}

The purpose of this study was to examine what influences voluntary CSR reporting in banking industry in Botswana. The study looked at the extent to which the size of the entity, years of operation and the listing status affect the level of CSR information dissemination. The results of this study suggest that size of the company as measured by asset value is good explanatory factor of extent of CSR disclosures in Botswana banks. Years of operation and listing status did not appear to be good predictors of level of voluntary dissemination of CSR information. However, a strong and positive relationship between CSR reporting and total assets and listing to Botswana stock Exchange was reported.

Despite entity age and listing status being weak predictors of CSR disclosure patterns, the study found that organization culture and governance structure appeared to affect engagement and disclosure of CSR activities by banks. For example, one bank of Asian origin did not report CSR activities, through its annual reports in all three years under consideration. Future studies in the African context should assess the effect of national culture, corporate culture, and country-of-origin culture on CSR activities and disclosure. Furthermore, in-depth studies that probe more qualitative data contained in company documents should reveal more about decisions to engage in CSR activities, and how listing status impacts on CSR participation decisions.

This study found that banks in Botswana disclose their involvement in CSR activities, especially community 
involvement and human resource related matters which they report voluntarily. The study proposes a more comprehensive and sustained approach to CSR engagement and reporting. Part of this requires greater corporate association by banks, possibly by coming together and cooperating under the auspices of their banking association to identify viable projects which they can invest in in order to effect long-term sustained community advancement. Banks should commit themselves to specified nominal percentage of their annual profits to be invested in CSR activities, an endeavor already realized by at least one bank operating locally. Most importantly, the legitimacy factor served by CSR reporting should be curtailed and replaced with intentions to make a meaningful and lasting impact on society. For example, a low to no disclosure on human resources by some banks suggests that some financial institutions are not committed to this venture, perhaps because of the weak negotiation position of their employees. As entities which aspire to become better corporate citizens, banks can engage in impactful projects such as the creation of scholarship funds for employees and community groups, and village electrification using solar systems, to mention but a few.

Currently the participation in CSR and the subsequent disclosure of such activities appears to be stimulated by some underlined competition motive. This is apparent in some CSR dimensions explored by the study, most notably community services which spread across the spectrum of identified variables for community dimensions disclosed. Measuring the efficacy of their contribution is difficult if it is not supported by agreed strategies for CSR involvement. The study calls for banks to adopt policies and strategies for CSR engagement and reporting after thorough research and careful consideration. Furthermore, the disclosure should indicate amounts contributed to CSR activities.

\section{References}

Abou-El-Fotouh, H. (2011). Corporate Social Responsibility in Banks: What does it mean? Go Articles. Retrieved $\quad 4^{\text {th }} \quad$ September $2017 \quad$ from http://ezinearticles.com/?Corporate-Social-Responsibility-in-Banks---What-Does-It-Mean?\&id=6411362

Abu-Baker, N., \& Naser, K. (2000). Empirical evidence on corporate social disclosure (CSD) practices in Jordan. International Journal of Commerce and Management, 10(3/4), 18-34. https://doi.org/10.1108/eb047406

Adams, C. A. (2002). International organizational factors influencing corporate social and ethical reporting: Beyond current theorising. Accounting, Auditing \& Accountability Journal, 15(2), 223-250. https://doi.org/10.1108/09513570210418905

Adams, C. A. (2008). A commentary on: Corporate social responsibility reporting and reputation risk management. Accounting, Auditing \& Accountability Journal, 21(3), 365-370. https://doi.org/10.1108/09513570810863950

Adams, C. A., Hill W. Y., \& Roberts, C. B. (1998). Corporate Social Reporting Practices in Western Europe: Legitimating corporate behaviors. Journal of British Accounting Review, 30(1), 1-21. https://doi.org/10.1006/bare.1997.0060

Akinpelu, Y. A., Ogunbi, O. J., Olaniran, Y. A., \& Ogunseye, T. O. (2013). Corporate social responsibility activities disclosure by commercial banks in Nigeria. European Journal of Business and Management, 5(7), 173-185.

Alsaeed, K. (2006). The association between firm-specific characteristics and disclosure: The case of Saudi Arabia. Managerial Auditing Journal, 21(5), 476-496. https://doi.org/10.1108/02686900610667256

Andabai, P. W. (2011). The emergence of banking sector reforms and the Nigerian economy: An in-depth analysis (2004-2008). The University Advanced Research Journal, (3), 35-38.

Argandoña, A. (2009). Can Corporate Social Responsibility Help to Understand the Credit Crisis? Presented to the Conference "Business Ethics and the Credit Crisis". University of North Carolina, Charlotte, March 31-April 1, 2009. Retrieved $\quad 1^{\text {st }} \quad$ September 2017 from https://link.springer.com/article/10.1007/s10551-010-0394-4

Bakan, J. (2004). The Corporation: The Pathological Pursuit of Profit and Power. London: Constable.

Baker, C. R., Cohanier, B., \& Pederzoli, D. (2012). Corporate social and environmental reporting in the large retail distribution sector. Procedia Economics and Finance, 2, 209-218. https://doi.org/10.1016/S2212-5671(12)00081-0

Bank of Botswana. (2014). Bank of Botswana Banking Supervision Annual Reports 2014. Gaborone: Bank of Botswana. 
Barton, H., \& Snider, K. F. (2012). Products that kill and Corporate Social Responsibility: The case of US Defence firms. Armed Forces and Society, 38(4), 604-625. https://doi.org/10.1177/0095327X11415490

Bearle, A., \& Meanse, G. (2002). The modern Corporation and Private Property. New Brunsvick: Transaction Publishers.

Beelitz, N., \& Merkl-Davies, D.M. (2012). Accounting Narratives and Impression Management in the Routledge Companion to Communication in Accounting. In Lisa Jack, Jane Davison and Russell Craig (Eds.). London: Routledge, Chapter 8, 109-132.

Bouma, J. J., Jeucken, M., \& Klinkers, L. (Eds.). (2001). Sustainable banking: the greening of finance. London: Greenleaf Pub.

Brammer, S., \& Pavelin, S. (2008). Factors influencing the quality of corporate environmental disclosure. Business Strategy and the Environment, 17(2), 120-136. https://doi.org/10.1002/bse.506

Branco, M. C., \& Rodrigues, L. L. (2006). Communication of corporate social responsibility by Portuguese banks: A legitimacy theory perspective. Corporate Communications: An International Journal, 11(3), 232-248. https://doi.org/10.1108/13563280610680821

Brown, N., \& Deegan, C. (1998). The public disclosure of environmental performance information-a dual test of media agenda setting theory and legitimacy theory. Accounting and Business Research, 29(1), 21-41. https://doi.org/10.1080/00014788.1998.9729564

Campbell, D. J. (2000). Legitimacy theory or managerial reality construction? Corporate social disclosure in Marks and Spencer Plc corporate reports, 1969-1997. Accounting Forum, 24(1), 80-100. Blackwell Publishers Ltd. https://doi.org/10.1111/1467-6303.00030

Carroll, A. B. (1991). The pyramid of corporate social responsibility: Toward the moral management of $\begin{array}{lllll}\text { organizational } & \text { stakeholders. } & \text { Business } & \text { 34izons, }\end{array}$ https://doi.org/10.1016/0007-6813(91)90005-G

Chhabra, E. (2014). Corporate Social Responsibilities, should it be a Law? Retrieved $16^{\text {th }}$ August 2017 from http://www.forbes.com/sites/eshachhabra/2014/04/18/corporate-social- responsibilityshould-it-be-a-law

Clarke, J., \& Gibson-Sweet, M. (1999). The use of corporate social disclosures in the management of reputation and legitimacy: a cross sectoral analysis of UK Top 100 Companies. Business Ethics: A European Review, $8(1), 5-13$. https://doi.org/10.1111/1467-8608.00120

Cowton, C. J. (2002). Integrity, responsibility and affinity: Three aspects of ethics in banking. Business Ethics: A European Review, 11(4), 393-400. https://doi.org/10.1111/1467-8608.00299

Cowton, C. J., \& Thompson, P. (2000). Do codes make a difference? The case of bank lending and the environment. Journal of Business Ethics, 24(2), 165-178. https://doi.org/10.1023/A:1006029327264

Damak-Ayadi, S. (2010). Social and environmental reporting in the annual reports of large companies in France. Accounting and Management Information Systems, 9(1), 22-44.

Davis, G., \& Searcy, C. (2010). A review of Canadian corporate sustainable development reports. Journal of Global Responsibility, 1(2), 316-329. https://doi.org/10.1108/20412561011079425

Dawood, U. (2014). Factors impacting profitability of commercial banks in Pakistan for the period of (2009-2012). International Journal of Scientific and Research Publications, 4(3), 1-7.

De la Cuesta-González, M., Muñoz-Torres, M. J., \& Fernandez-Izquierdo, M. A. (2006) Analysis of social performance in the Spanish financial industry through public data. A proposal. Journal of Business Ethics, 69(3), 289-304. https://doi.org/10.1007/s10551-006-9091-8

Decker, O. S. (2004). “Corporate social responsibility and structural change in financial services." Managerial Auditing Journal, 19(96), 712-728. https://doi.org/10.1108/02686900410543840

Deegan, C. (2002). Introduction: The legitimising effect of social and environmental disclosures-a theoretical foundation. Accounting, Auditing \& Accountability Journal, 15(3), 282-311. https://doi.org/10.1108/09513570210435852

Deegan, C., \& Gordon, B. (1996). A study of the environmental disclosure practices of Australian corporations. Accounting and business research, 26(3), 187-199. https://doi.org/10.1080/00014788.1996.9729510

DeGeorge, R (2010). Business Ethics. Upper Saddle River. Pearson Education. 
Dhar, S., \& Mitra, S. (2010). Extent and determinants of corporate social reporting in India. Indian Accounting Review, 14(2), 57-78.

Dineshwar, R. (2013). Corporate social reporting by Mauritian banks. In Proceedings of 3rd Asia-Pacific Business Research Conference (25-26).

Doane, D. (2005). Beyond corporate social responsibility: minnows, mammoths and markets. Futures, 37(2), 215-229. https://doi.org/10.1016/j.futures.2004.03.028

Dorasamy, N. (2013). Corporate Social Responsibility and Ethical Banking for Developing Economies. Journal of Economics and Behavioral Studies, 5(11), 777-785.

Douglas, A., Doris, J., \& Johnson, B. (2004). Corporate social reporting in Irish financial institutions. The TQZ Magazine 16(6), 387-395. https://doi.org/10.1108/09544780410563301

Dowling, J., \& Pfeffer, J. (1975). Organizational legitimacy: Social values and organizational behavior. Pacific Sociological Review, 18(1), 122-136. https://doi.org/10.2307/1388226

Falck, O., \& Heblich, S, (2007). Corporate Social Responsibility: Doing well by doing good. Business Horizons Journal, 50(3), 247-254. https://doi.org/10.1016/j.bushor.2006.12.002

Firth, M. (1979). The Impact to Size, Stock Market Listing, and Auditors on Voluntary Disclosure in Corporate Annual Reports. Journal of Accounting and Business Research, 9(1), 273-280. https://doi.org/10.1080/00014788.1979.9729168

Friedman, A. L., \& Miles, S. (2002). Developing stakeholder theory. Journal of management studies, 39(1), 1-21. https://doi.org/10.1111/1467-6486.00280

Frynas, J. (2012). Corporate social responsibility or government regulation? Evidence on oil spill prevention. Ecology and Society, 17(4). Article 4. https://doi.org/10.5751/ES-05073-170404

Global Reporting Initiative. (2007). Sustainability Reporting Guidelines. Retrieved $12^{\text {th }}$ October 2016 from https://www.globalreporting.org/.../GRI-Sustainability-Report-2004-2007.pdf

Gough, I. (2008). European welfare states: Explanations and lessons for developing countries. Inclusive states: Social Policy and Structural Inequalities, 39-72.

Gray, R., Owen, D., \& Adam. C. A. (1996) Accounting and Accountability: Changes and Challenges in Corporate Social and Environmental Reporting. London: Prentice Hall.

Greenbaum, S.I. \& Thakor, A.V. (2007). Contemporary Financial Intermediation (2nd ed.). London: Academic Press Advanced Finance.

Grougiou, V., Leventis, S., Dedoulis, E., \& Owusu-Ansah, S. (2014). Corporate social responsibility and earnings management in US banks. Accounting Forum, 38(3), 155-169. https://doi.org/10.1016/j.accfor.2014.05.003

Guthrie, J., \& Abeysekera, I. (2006). Content analysis of social, environmental reporting: What is new? Journal of Human Resources Costing and Accounting, 10(2), 114-126. https://doi.org/10.1108/14013380610703120

Guthrie, J., \& Parker, L. D. (1989). Corporate Social Reporting: A Rebuttal of Legitimacy Theory. Accounting and Business Research, 19(76), 343-352. https://doi.org/10.1080/00014788.1989.9728863

Hackston, D., \& Milne, M (1996). Some Determinants of Social and Environmental Disclosure in New Zealand Companies. Accounting Auditing \& Accountability Journal, 9(1), 77-108. https://doi.org/10.1108/09513579610109987

Hamid, F. Z. A. (2004). Corporate social disclosure by banks and finance companies: Malaysian evidence. Corporate Ownership and Control Journal, 1(4), 118-130. https://doi.org/10.22495/cocv1i4p10

Handelman, J. M., \& Arnold, S. J. (1999). The role of marketing actions with a social dimension: Appeals to the institutional environment. International Journal of Marketing, 63(7), 38-48. https://doi.org/10.2307/1251774

Harikkala, R. (2010). CSR in the Finnish Banking Industry. Bachelor's Thesis in International Business.

Hasnas, J. (1998). The normative theories of business ethics: a guide for then perplexed. Business Ethics Quarterly, 8(1), 19-42. https://doi.org/10.2307/3857520

Hawashe, A., \& Ruddock, L. (2014). An evaluation of voluntary disclosure in the annual reports of commercial banks: empirical evidence from Libya. In Salford Postgraduate Annual Research Conference in April, 2014 (p. 217). 
Hillman, A. J., \& Keim, G. D. (2001), Shareholder value, stakeholder management and social issues: what's the bottom line? Strategic Management https://doi.org/10.1002/1097-0266(200101)22:2<125::AID-SMJ150>3.0.CO;2-H

Hooghiesmtra, R. (2000). Corporate communication and impression management- New perspectives why companies engage in corporate social reporting. Journal of Business Ethics, 27(1/2), 55-68. https://doi.org/10.1023/A:1006400707757

Hosmer, L. T. (1994), Strategic planning as if ethics mattered. Strategic Management Journal, 15(1), 17-34. https://doi.org/10.1002/smj.4250151003

Idowu, S. O, \& Papasolomou, I. (2007). Are the corporate social responsibility matters based on good intentions or false pretences? An empirical study of the motivations behind issuing of CSR reports by UK companies. Journal of Corporate Governance, 7(2), 136-147. https://doi.org/10.1108/14720700710739787

Ismail, K. N. I. K., \& Ibrahim, A. H. (2008). Social and environmental disclosure in the annual reports of Jordanian companies. Issues in Social and Environmental Accounting, 2(2), 198-210. https://doi.org/10.22164/isea.v2i2.32

Jefferis, K., \& Tacheba, A. (2010). Botswana Financial Sector Overview 2009/10. Gaborone: Capital Resources (Pty) Limited.

Kim, M. (2011). Motivations for engaging in Corporate Social Responsibility Reporting. Comparative Study among different Industries in Sweden. Master's Thesis.

Kolk, A. (2004). A decade of sustainability reporting: developments and significance. International Journal of Environment and Sustainable Development, 3(1), 51-64. https://doi.org/10.1504/IJESD.2004.004688

KPMG (2005). KPMG international survey of corporate responsibility reporting. KPMG Global Sustainability Services.

Kunt-Demirguc, A., Klapper, L., Singer, D., \& Van Oudheusden, , P. (2015). The Global Findex Database $2014-$ Measuring Financial Inclusion Around the World, World Bank Policy Research. https://doi.org/10.1596/1813-9450-7255

Lachowicz, M. (2000). The Listening Banks: The Development of Stakeholder Relations with NGOs. Sheffield Greenleaf. https://doi.org/10.9774/GLEAF.978-1-907643-14-9_9

Lawrence, A. T., \& Weber, J. (2008). Business and society: Stakeholders, ethics, public policy. Tata McGraw-Hill Education.

Lenka, B., \& Jiří, P. (2014). Corporate Social Responsibility in Commercial Banking - A Case Study from the Czech Republic. Journal of Competitiveness, 6(1), 50-70. https://doi.org/10.7441/joc.2014.01.04

Lentner, C., Szegedi K. \& Tatay, T. (2015). Corporate Social Responsibility in the Banking Sector. Public Finance Quarterly, 60(1), 95-103.

Lima-Ribeiro V. P., Da Silva Monteiro, S. M., \& Guzmán C. A. (2012). Determining factors of environmental management practices in Portuguese local entities. Management of Environmental Quality: An International Journal, 23(5), 486-502. https://doi.org/10.1108/14777831211255079

Luo, X., \& Bhattacharya, C. B. (2006). Corporate social responsibility, customer satisfaction, and market value. Journal of marketing, 70(4), 1-18. https://doi.org/10.1509/jmkg.70.4.1

Margolis, J. D., \& Walsh, J.P (2003). Misery loves companies: rethinking social initiatives by business. Administrative Science Quarterly Journal, 48(1), 268-305. https://doi.org/10.2307/3556659

Mathews, M. R. (1997). Twenty-five years of social and environmental accounting research. Accounting, Auditing \& Accountability Journal, 10(4), 481-531. https://doi.org/10.1108/EUM0000000004417

Mathews, M. R., \& Perera, M. H. B. (1996). Accounting Theory and. Development. International Thompson Publishing Company. South Melbourne.

Mayo, E. (1997). Policy responses to financial exclusion. In Rossiter, J. (Ed.), Financial Exclusion: Can Mutuality Fill the Gap? New Policy Institute, London.

Mbekomize, C. J., \& Dima, W. L. (2013). Social and Environmental Disclosure by Parastatals and Companies Listed on the Botswana Stock Exchange. Journal of Management and Sustainability, 3(2), 66-73. https://doi.org/10.5539/jms.v3n3p66 
Milne, M. J., \& Adler, R. W. (1999). Exploring the reliability of social and environmental disclosures content analysis. Accounting, Auditing \& Accountability Journal, 12(2), 237-256. https://doi.org/10.1108/09513579910270138

Mishra, S., \& Suar, D. (2010). Does corporate social responsibility influence firm performance of Indian companies? Journal of business ethics, 95(4), 571-601. https://doi.org/10.1007/s10551-010-0441-1

Mitchell, R. K., Agle, B. R., \& Wood, D. J. (1997). Toward a theory of stakeholder identification and salience: Defining the principle of who and what really counts. Academy of Management Review Journal, 22(4), 853-886. https://doi.org/10.5465/AMR.1997.9711022105

Mitroff, I. I. (1983). Stakeholders of the organizational mind. San Francisco, CA: Jossey-Bass Inc Pub.

Moffat, B. (2009). The Banking Environment in Botswana: An Overview, Botswana Notes and Records, 41, 95-103.

Morsing, M., \& Schultz, M. (2006). Corporate social responsibility communication: stakeholder information, response and involvement strategies. Journal of Business Ethics: An European Review, 15(4), 323-338. https://doi.org/10.1111/j.1467-8608.2006.00460.x

Nikolaou, I. E. (2007). Environmental accounting as a qualitative improvement of banks service. International Journal of Financial Service Management, 2(2), 133-135. https://doi.org/10.1504/IJFSM.2007.011677

Nikolova, V., \& Arsić, S. (2017). The Stakeholder Approach in Corporate Social Responsibility. Engineering Management, 3(1), 24-35.

O’Donovan, G. (2002). Environmental disclosures in the annual report: Extending the applicability and predictive power of legitimacy theory. Accounting, Auditing \& Accountability Journal, 15(3), 344-371. https://doi.org/10.1108/09513570210435870

Parsa, S., \& Kouhy, R. (2008). Social reporting by companies listed on the alternative investment market. Journal of Business Ethics, 79(3), 345-360. https://doi.org/10.1007/s10551-007-9402-8

Patten, D. M. (1991). Exposure, Legitimacy, and Social Disclosure. Journal of Accounting and Public Policy, 10(1), 227-308. https://doi.org/10.1016/0278-4254(91)90003-3

Patten, D.M. (1992). Intra-industry environmental disclosures in response to Alaskan Oil spill: A note on legitimacy theory. Journal of Accounting Organizations and Society, 17(5), 471-475. https://doi.org/10.1016/0361-3682(92)90042-Q

Price, A. (2004). Human Resource Management in a Business Context (2nd ed.). London: Thomson Learning Publisher.

Pricewaterhouse Coopers. (2008). Building the case for wellness. PricewaterhouseCoopers LLP.

Ragodoo, N.J.F., (2009). CSR as a tool to fight against poverty: The case of Mauritius. Social Responsibility Journal, 5(1), 19-33. https://doi.org/10.1108/17471110910939971

Rahim, M. M. (2013). Legal regulation of corporate social responsibility: A meta-regulation approach of law for raising CSR in a weak economy. Springer-Verlag. Berlin Heidelberg. https://doi.org/10.1007/978-3-642-40400-9

Richards, M., Palmer, P., \& Bogdanova, M. (2008). Irresponsible Lending? A case study of a UK credit industry reform initiative. Journal of Business Ethics, 81(3), 499-512. https://doi.org/10.1007/s10551-007-9520-3

Roberts, R. W. (1992). Determinants of corporate social responsibility disclosure: An application of stakeholder theory. Accounting, organizations and society, 17(6), https://doi.org/10.1016/0361-3682(92)90015-K

Sacconi L. (2004). Corporate social responsibility (CSR) as a model of 'extended' corporate governance: An explanation based on the economic theories of social contract, reputation and reciprocal conformism. LIUC, Ethics, Law and Economics Paper No. 142. https://doi.org/10.2139/ssrn.514522

Savage, A., Cataldo, A. J., \& Rowlands, J. (2000), A Multi-Case Investigation of Environmental Legitimation in Annual Reports. Advances in Environmental Accounting and Management, 1, 45-81. https://doi.org/10.1016/S1479-3598(00)01005-0

Scholtens, B. (2006). Finance as a driver of corporate social responsibility. Journal of Business Ethics, 44(1), 49-59. https://doi.org/10.1007/s10551-006-9037-1 
Sedler, R. F. (1967). Social Welfare in a Developing Country: the Ethiopian Experience. International Social Work, 10(4), 1-12. https://doi.org/10.1177/002087286701000401

Shocker, A. D., \& Sethi, S. P. (1974). An approach to incorporating action preferences in developing corporate action strategies. The unstable ground: Corporate in a dynamic society, Melville, CA.

Shukla, A. K. ( 2013). Corporate social responsibility and accountability, vsrd International Journal of Business and Management Research, 3(7), 285-288.

Simms, J. (2002). Business: corporate social responsibility-you know it makes sense. Accountancy, 130(1311), 48.

Strandberg, C. (2005). Best practices in sustainable finance. Strandberg Consulting. Retrieved $10^{\text {th }}$ September 2017 from https://www.cbd.int/financial/privatesector/several-privatebestpractices.pdf

Szymanski, D. M., \& Henard, D. H. (2001). Customer Satisfaction: A meta-analysis of the empirical evidence. Journal of the Academy of Marketing Science, (29), 16-35. https://doi.org/10.1177/0092070301291002

Tarna, K. (1999). Reporting on the environment: current practice in the financial services sector. Greener Management International, 26, 49-64.

Thompson, P., \& Cowton, C. J. (2004). Bringing the environment into bank lending: Implications for environmental reporting. British Accounting Review Journal, 36(2), 197-218. https://doi.org/10.1016/j.bar.2003.11.005

Tilling, M. V. (2004). Some thoughts on legitimacy theory in social and environmental accounting. Social and Environmental Accountability Journal, 24(2), 3-7. https://doi.org/10.1080/0969160X.2004.9651716

Unerman, J. (2000). Methodological issues-Reflections on quantification in corporate social reporting content analysis. Accounting, Auditing \& Accountability Journal, 13(5), 667-681. https://doi.org/10.1108/09513570010353756

Wagg, O. (2010). Briefing: banks and finance. Ethical Corporation, June, 1-10.

Wartick, S. L., \& Mahon, J. F. (1994). Toward a substantive definition of the corporate issue construct: a review and synthesis of the literature. Business and Society, 33, 293-311. https://doi.org/10.1177/000765039403300304

Woodward, D. G., Edwards, P., \& Birkin, F. (1996). Organizational legitimacy and stakeholder information provision. British Journal of Management, $\quad 7(1), \quad 329-347$. https://doi.org/10.1111/j.1467-8551.1996.tb00123.x

Zadek, S., Raynard, P., Forstater, M., and Oelschlaegel, J. (1997). The future of sustainability assurance. London: Certified Accountants Educational Trust.

Zappi, G. (2007). Corporate responsibility in the Italian banking industry: creating value through listening to stakeholders. Corporate Governance: The international journal of business in society, 7(4), 471-475. https://doi.org/10.1108/14720700710820542

Zeghal, D., \& Ahmed, S. A. (1990). Comparison of social responsibility information disclosure media used by Canadian firms. Accounting, Auditing \& Accountability Journal, 3(1), 38-53. https://doi.org/10.1108/09513579010136343

\section{Note}

Note 1. As at September 16, 2017 the exchange rate was US\$ $1=$ BWP10.10

\section{Copyrights}

Copyright for this article is retained by the author(s), with first publication rights granted to the journal.

This is an open-access article distributed under the terms and conditions of the Creative Commons Attribution license (http://creativecommons.org/licenses/by/4.0/). 